\title{
From Emancipation to Silent Submission: A Study of Some of the Prominent Female Characters of Ruth Prawer Jhabvala
}

\author{
Dr. Suprita Jha
}

Associate Professor, Department of English, Mata Sundri College, University of Delhi, India

Received: 10 Jun 2021; Received in revised form: 04 Jul 2021; Accepted: 16 Jul 2021; Available online: 24 Jul 2021 (C2021 The Author(s). Published by Infogain Publication. This is an open access article under the CC BY license (https://creativecommons.org/licenses/by/4.0/).

\begin{abstract}
It is often said that Ruth Prawer Jhabvala writes about the ironical situations that obtain in the urban middle class Indian life, particularly in undivided Hindu families, as also about the impact of EastWest encounter in India. It is also true that R.P. Jhabvala cannot be considered an 'insider': nevertheless, it is because of her long stay in India that she has to be considered as a writer who has seen and written about this country from the inside.In her novels, the women characters feel that they grow smaller everyday trapped in a myth of the role of wife and mother. Jhabvala as a major woman novelist is less concerned with personality delineation of her women characters.This paper attempts to show how her some of her female characters don't go against tradition without any firm conviction.
\end{abstract}

Keywords - East-west, insider-outsider, tradition, modernity, authority, marriage, education, rebel, confront, passionate.

\section{INTRODUCTION}

If Kamala Markandaya is 'an insider-outsider', then Ruth Prawer Jhabvala may be looked upon as 'outsider-insider', though she has said over again and again that she should in no case be considered to be an Indian writer. According to her, she, in all fairness, should be regarded as 'one of those European writers who have written about India'.Prof Shahane observes,' the major themes in Jhabvala's fiction are "East-West encounter" and "marital dissonance" which are mutually interlinked in their negative context. In the positive context, these may be described as fruitful and happy relationships between East and West culminating in marital harmony and joy'. Jhabvala portrays both these aspects, but the elements of encounter and dissonance dominate her human world'. In spite of her Polish parentage, German upbringing and British schooling 'her best work reveals such inwardness in her picture of certain segments of Indian social life, that it is difficult to consider her as an 'outsider' in an obvious sense. Jhabvala is very clear in her mind when she says: 'If I hadn't married an Indian, I don't think I would even have come here for I am not attracted or used not to be attracted to the things that usually bring people to India'.

Ruth Prawer Jhabvala has written many significant novels in which she has portrayed her female characters with a particular but definite perspective. Her first novel, TO WHOM SHE WILL, came out in 1955, and it has been followed by such of her other novels as THE NATURE OF PASSION(1956), ESMOND IN INDIA(1958), THE HOUSEHOLDER(1960), GET READY FOR BATTLE(1962), A BACKWARD PLACE(1965), A NEW DOMINION(1973), HEAT AND DUST(1975) and few more. Some of these novels are the comedies of urban middle-class Indian life, particularly of undivided Hindu families, while the others are the ironic studies of EastWest encounter. As we go through Ms. Jhabvala's novels, we encounter such principal female characters in them, as Amrita and Sushila in TO WHOM SHE WILL, Nimmi in THE NATURE OF PASSION, Gulab and Shakuntala in ESMOND IN INDIA, Indu in THE HOUSEHOLDER, 
Sarla Devi and Kusum in GET READY FOR BATTLE, Judy in A BACKWARD PLACE, Lee in A NEW DOMINION, Olivia in HEAT AND DUST, Harriet in THREE CONTINENTS etc. One common characteristic we find in almost all of her female characters is that they are quite capable of taking their own stands but ultimately they surrender in front of the social compulsions. The following study of some of her female Indian characters' psychology can be seen as the basic portrayal of Jhabvala's all the major female characters in her other novels too.

\section{TO WHOM SHE WILL}

In her novel TO WHOM SHE WILL, Amrita is a Bengali girl who belongs to a respectable and aristocratic family presided over by her anglicized grandfather, Pandit Ram Bahadur. She works as an announcer in the All India Radio and the person she loves and wishes to marry is Hari Sahni, a Punjabi youth, who is her associate there itself. It is quite early in the course of their love-relationship that Amrita informs Hari of her grandfather's opposition to the very idea of their marriage, however, 'she blurts out...... I do not care about what grandfather says, believe me. Hari, I do not care what any of them say...... Please, believe me, Please. What does my family matter? You know I would give up everyone and everything for you. Nothing matters, only you". Amrita declares to Hari that she does not care about her grandfather's or anybody's opposition to their love-relationship and in his own turn Hari looks upon Amrita as a 'goddess'. It looks as if they are determined to defy their families and social conventions. As we find her, she is rebellious enough to turn down her grandfather's proposal to her to leave for England. Instead, she prefers to stay with Hari in India itself. She tells Hari: 'You are my life', she said...'It is that I love you. And you love me. What else matters'?

It is really ironic that while Amrita too does not go to England, she does not marry Hari, instead she marries Krishna Sengupta who has been a paying guest in her house and who has been working as her messenger to Hari. It is all the more ironic that Krishna who tries so very sincerely to bridge the gap between Amrita and Hari, fills in the gap himself. Amrita's mother, Radha, considers her daughter to be 'very obstinate, headstrong girl'. Her aunt, Tarala, however, has a different view of her, and is all sympathy for her. Amrita does behave as a self-willed, romantic and nonconformist girl, and decides to give herself 'to whom she will', but she does not succeed, and true to the spirit of conformism marries Krishna Sengupta.

Hari Sahni marries Sushila Anand, a girl of his own community; theirs is a negotiated, arranged marriage.
Sushila is a beautiful girl; she is gifted with a melodious voice, and is both dynamic and intelligent. And though Hari's sister, Prema, is herself estranged from her husband, she is conventional enough to say to her brother,'You and Sushila. We think it is best for you: she will give you happiness'. Here we have two completely different characters-Amrita and Sushila. Sushila believes in traditional parental authority, while Amrita tries to defy it. However, it is because of the compulsion of the circumstance that Amrita succumbs to conventional pressures. Whatever is the situation, the final result is that both Amrita and Sushila have to suffer in their lives on the names of convention and tradition.

\section{THE NATURE OF PASSION}

In her next novel THE ATURE OF PASSION Jhabvala's canvas is primarily familial, though it includes many other related areas especially of a society which is involved in a state of change from an orthodox to a modern mode of living. It is in the context of this very change that we have to undertake a study of Nimmi's character. Nimmi is the youngest daughter of Lala Narayan DasVerma, known practically throughout the novel as Lalaji. He has migrated to Delhi from Punjab after the partition of the Indian subcontinent, and it is indeed a tribute to his worldly skill that he has acquired plenty of wealth to make his large family extremely comfortable at the new place too. The nature of his passion; as we find it, is rajas, and we know him chiefly by his possessiveness, his acquisitiveness, his belief in wealth. And yet, this money-obsessed patriarch, indulging in various nefarious deals, has a great passion for Nimmi, so much so that with all his orthodoxy and remonstrances from the other elderly members of the family he readily condones all her lapses. He looks upon Nimmi as 'his treasure, his pride, his finest achievement', and dreams of her marriage as a grand affair.

This eighteen-year old girl, Nimmi, belongs to the Neorich class of Delhi and it is nothing unnatural that her quest of culture is so very typical of the 'nouveau riche'. She goes to the clubs and hotels frequently, longs for an emancipated life, and does everything possible to break away from the stifling orthodoxy of her family in a spirit of gay abandon. She revolts against the restrictions imposed on the young girls in tradition-bound Indian families as also against the prevailing system of arranged marriage accompanied by dowries. Her passion for Pheroze Batliwala, a Parsee youth, is a reflection of this very spirit of her revolt, though in a strikingly adolescent and sentimental way she is charmed by his handsome looks and his angliciseddemeanour. And it is in her quest for culture or pseudo-culture that she gets her hair cut 
short. As we find, while Nimmi's mother and Phuphiji react violently to this outrage, Lalaji's reaction ti this hair cut is different. It is really extraordinary that Lalaji ignores the whole thing with 'a benign solicitude'.

Nimmi admires her liberated and snobbish sister-in-law, Kanta, gets lured away by the glamour of her sophistication, and tries to imitate her ways, though they all depend upon Lalaji's money. As and what she is, Nimmi would have ruined herself because of her unchecked passion for wantonness which she mistakes for modernity. Her attraction for Pheroze, we find, has its own sensuousness. Her character is dotted with multiple blind spots, for she is an utterly spoiled girl. However, it is her father's shrewdness and money that save her from damnation, and ironically enough, like Amrita in TO WHOM SHE WILL, Nimmi's marriage is arranged, and the husband chosen for her is none other than her new friend, Kuku, who belongs to her own religion and community. Here is a character, Nimmi, young, adolescent, sentimental and capricious, who mistakes love for licence, culture for glamour, modernity for wantonness, self-cultivation for imitativeness, higher education for a defiance of established norms. It is indeed ironic that she is tied to the bond of marriage patently according to the convention and she accepts it as her fate.

\section{ESMOND IN INDIA}

In ESMOND IN INDIA, as Professor Iyenger puts it,"the strands of comedy, irony and satire mingle and fuse to make a fabric of fiction that tenses and fascinates at once". As we go through this novel we see that while it is the nature of Gulab-Esmond relationship that forms the core of its narrative, the nature of Shakuntala-Esmond relationship too has its own importance and value. Gulab is an Indian girl, who gets enamoured of a handsome Englishman named Esmond Stillwood, elects to be his wife, and marries him. We see them together in the fifth chapter of the novel when they are already alienated from each other on account of pronounced differences in their tastes and attitudes. Much of the annoyance of her husband, Gulab brings up the child, Ravi, as per the Indian way, and she herself eats and at sleeps on the floor, and does never conceal her fondness for spicy food. That is why, while in the company of Gulab, Esmond feels so miserable and angry, in that of mental state he finds himself so happy and comfortable in the company of Betty. Betty seems to Esmond to be 'so light, modern and airy too. Being with her was almost as good as being in England'. It is no surprise that Esmond, a bull and a culture snob, looks upon Gulab as a dirty, stupid and slovenly character, but it is really surprising that Gulab remains so passive in the face of her husband's sarcasm and sneer. He tells Gulab:

'You've got what I can call a wonderful propensity to squalor. Tell me now, if pressed on the point, would you call yourself a slut'?

It is indeed extraordinary that Gulab, an educated Indian woman, does not react to what Esmond says and that, instead, we find her cold, frigid, stony and unresponsive. However, in spite of his being a vain and pompous and unscrupulous Westerner, Esmond praises Gulab in the presence of others, as he does in the presence of Shakuntala. He tells this lady visitor to his house: 'yes, my wife's quite an interior decorator.....colour schemes are her speciality'. Gulab leaves Esmond for the reason that her servant tries unsuccessfully to molest her during the period of her husband's prolonged absence. She believes that her husband, whatever else might be true of him, must offer her due protection. Not unexpectedly, she packs up and goes away from him for good.

It is not at all difficult to see that Gulab's character has its own ambiguities. To begin with, it is as a rebel, as a nonconformist that Gulab defies her mother and uncle, rejects Amrit, and marries Esmond. Then suddenly she becomes so passive and so obsequious as to suffer her husband's tantrums and assaults without any murmur. She manages to remember what her mother has told her:

'a husband is a woman's God-how Sita submitted to Ram; she followed him into wilderness and afterwards when he banished her, she turned and went without a word, though she was innocent'. And this is how she consoles and comforts herself: 'her instinct had told her that she must, whatever he might do to her, stay with Esmond since he was her husband and therefore her God...'. It was a husband's right, so her instinct told her, to do whatever he liked with his wife. He could treat her well or badly, pamper her or beat her-that was up to him , and it was not her right to complain. Gulab's image as a rebel, we see, does not and cannot square up with her Sita image: the entire thing looks so ironic.

Shakuntala, Gulab's classmate, is Mr. Her Dayal's daughter and favourite. Her father is a Cambridgeeducated person, a careerist, and is extremely fond of western education and culture, of art and music and poetry. He encourages Shakuntala to cultivate her personality, to develop her own identity, and in the process does not mind her having a drink os smoke at a party. She gets thrilled by Esmond's handsomeness when she first meets him, and quite expectedly she gets all the more thrilled when he is appointed her tutor. Fed on the romantic notions of love, she falls an easy prey to thr temptations of the flesh. Mr. Her Dayal just cannot understand the irony implicit in his 
own statement when, speaking about Esmond, he says,'I believe his fees are quite reasonable, considering the excellent service he gives'. Shakuntala is so passionate, so sentimental and so sensual indeed, and though Esmond retorts by saying:'Hearts don't burst that easily...no, no, I am not laughing at you, but do try and be sensible', that very night they go to bed together in the hotel room at Agra. Shakuntala moves about gaily in Delhi with Esmond, and even as she feels happy and satisfied, Esmond thinks of Betty and of their journey together to England, he has nothing of love for her, in fact, she is just one of his easy conquests. Here too we find everything so incongruous in her character that she never tries to shew any authority on Esmond.

\section{CONCLUSIONS}

It is important to note that while on the one hand MS. Jhabvala writes in her novels about the joys and sorrows of urban middle-class undivided Hindu families, and presents in them a picture of cultural conflict, a conflict between tradition and modernity, that plagues most of these families, on the other she describes India as a backward place, a place where the westerners can get no peace and where they have only to suffer and suffer unmitigated because of disease and sexual abuse. However, here is a novelist who gives us a host of individuals, types and caricatures in the form of her female characters who are sometimes caught up in the coils of East-West encounter and sometimes in certain conventions on the name of society. Ms. Jhabvala may claim, as she does, that she is a European writer and that she is not at all an Indian writer, but the truth is that she cannot be looked upon as an outsider. There is absolutely no doubt about the fact that she has experienced and understood Indian culture as per her own point of view. Obviously we cannot overlook her experience in India as the wife of an Indian Parsi Architect. In any case, it is indeed ironic that these female characters have their own dreams and desires but they have to sacrifice them on the name of our tradition and culture. This silent submission of these characters from emancipation's very well executed by R.P.Jhabvala in her novels. In the battle between tradition and modernity, conformity and nonconformity that takes place in her novels, it is tradition that prevails over modernity, conformity over nonconformity.

\section{REFERENCES}

[1] M. K. Naik, A History of Indian English Literature.

[2] R. P. Jhabvala, 'Living in India”, London Magazine.

[3] K. R. S. Iyenger, Indian Writing in English.

[4] R. P. Jabvala, TO WHOM SHE WILL.
[5] V. A. Shahane, Ruth Prawer Jhabvala.

[6] R. P. Jhabvala, THE NATURE OF PASSION.

[7] R. P. Jhabvala, ESMOND IN INDIA. 